\title{
Pengaruh Pembelajaran Berbasis Masalah (PBM) dengan Bantuan Geogebra Terhadap Kemampuan Spasial Mahasiswa
}

\author{
Abd. Haris ${ }^{1}$, Arif Rahman ${ }^{2}$ \\ ${ }^{1,2}$ STKIP Taman Siswa Bima \\ ${ }^{1}$ haris.suksesuny@gmail.com
}

\begin{abstract}
ABSTRAK
Salah satu kemampuan yang harus dimiliki oleh mahasiswa adalah kemampuan spasial. Obyek tiga dimensi adalah pembahasan yang sering membuat mahasiswa kesulitan. Mereka kesulitan dalam membuat hubungan-hubungan antarobyek dalam ruang. Komputer adalah media yang baik untuk pembelajaran matematika, terutama untuk memvisualisasikan obyek-obyek abstrak. Sejalan dengan tujuan penlitian ini, untuk dapat mendukung peningkatan kemampuan spasial mahasiswa dapat diberikan melalui Pembelajaran Berbasis Masalah (PBM) dengan bantuan Geogebra. Geogebra adalah suatu sistem Geometri dinamis yang dapat membantu melakukan konstruksi dengan titik-titik, vektorvektor, segment, bentuk, dan lainya. Penelitian ini adalah penelitian eksperimen semu dengan desain pretest-posttest non equivalent group design. Obyek penelitian ini diambil secara acak dua kelas, yaitu satu kelas eksperimen dan satu kelas kontrol. Teknik analis data yang digunakan pada penelitian ini adalah statistik uji one sample t-test, two group ANOVA, dan independent $t$ test dengan SPSS for windows. Hasil penelitian menunjukkan bahwa: (1) PBM pada materi Geometri berbantuan Geogebra berpengaruh terhadap kemampuan spasial, (2) metode pembelajaran konvensional berpengaruh terhadap kemampuan spasial, dan (3) PBM pada materi Geometri berbantuan Geogebra lebih berpengaruh signifikan dibandingkan dengan metode Konvensional terhadap kemampuan spasial mahasiswa.
\end{abstract}

Kata kunci : kemampuan spasial, PBM, geogebra

\section{PENDAHULUAN}

Turgut \& Yilmaz (2012) mengatatakan bahwa ada hubungan positif antara kemampuan spasial dan kesuksesan akademis. Mahasiswa yang mempunyai kemampuan spasial yang tinggi memiliki prestasi matematika yang lebih tinggi dibandingkan dengan mahasiswa yang memiliki kemampuan spasial yang sedang dan rendah (Faradhila, Sujadi, dan Kuswardi, 2013). Selama 50 tahun, dokumen-dokumen penelitian telah membuktikan bahwa kemampuan spasial mempunyai peranan penting dalam bidang pekerjaan dan pendidikan (Lubinski, 2010).

Keharusan memiliki kemampuan spasial dalam pembelajaran di sekolah dan pekerjaanpekerjaan tertentu telah diakui secara global oleh para peneliti dalam bidang psikologi dan pendidikan (Yilmaz, 2009). Hal ini dapat dilihat dari adanya pembelajaran geometri di sekolahsekolah dalam berbagai jenjang dan tes kemampuan spasial yang menjadi tes wajib dalam berbagai bagian dari tes psikologi ketika seseorang akan menempuh pendidikan tinggi dan memasuki dunia kerja di perusahaanperusahaan tertentu.

Demikian pentingnya kemampuan spasial dan perlu dimiliki oleh mahasiswa sehingga dosen dituntut untuk memperhatikan kemampuan ini dalam pembelajaran di kelas. Ahmad \& Jaelani (2015) kemampuan spasial harus dimiliki oleh mahasiswa pendidikan matematika untuk mendukung pengembangan ilmunya. Sayangnya tidak semua mahasiswa pendidikan matematika mempunyai kemampuan spasial tinggi sebagai suatu cerminan pada bidang ilmunya. Para mahasiswa tersebut masih kesulitan dalam menyelesaikan masalah yang berhubungan dengan keruangan terutama jika dihadapkan pada obyek berdimensi tiga. Mereka kesulitan dalam membuat hubungan-hubungan antar obyek dalam ruang.

Muslim \& Haris (2017) mengungkapkan program komputer (software) yang dapat dimanfaatkan sebagai media pembelajaran matematika, khususnya Geometri, adalah 
Geogebra. Dengan program Geogebra, objek-objek Geometri yang bersifat abstrak dapat divisualisasi sekaligus dapat dimanipulasi secara cepat, akurat, dan efisien. Program Geogebra berfungsi sebagai media pembelajaran yang memberikan pengalaman visual kepada siswa dalam berinteraksi dengan konsep-konsep Geometri

Berdasarkan hasil pengamatan peneliti selama mengajar di STKIP Taman Siswa Bima, mahasiswa mengatakan bahwa pembelajaran geometri termasuk pembelajaran yang membutuhkan waktu yang lama untuk memahaminya. Diperlukan sebuah solusi untuk menyelesaikan permasalahan yang ada di lapangan dan sebagai modal mahasiswa sebagai calon guru utuk mengajarkan kepada peserta didiknya. Maka dari itu pemilihan media pembelajan dirasa tepat oleh peneliti menjadi alat yang baik untuk digunakan dalam pembelajaran geometri, dan berdasarkan hasil wawancara peneliti dengan Dosen matematika masih jarang pengunaan software dalam pembelajaran matematika. Sehubungan dengan hasil riset Global Creativity Index (GCI, 2011) penelitian ini melakukan perbandingan kreatifitas dalam berbagai inovasi dan teknologi diberbagai negara di dunia yang menempatkan posisi Indonesia di 81 dari 82 negara yang menjadi partisipan.

Penggunaan media dalam pembelajaran geometri haruslah dikemas melalui suatu model pembelajaran. Berbagai model pembelajaran yang dapat dipadukan dengan Geogebra. Salah satu model yang dapat digunakan adalah Pembelajaran Berbasis Masalah (PBM). Dipilihnya PBM karena PBM adalah model pengajaran yang bertitik tolak dari human activity, menekankan keterampilan 'procces of doing mathematics', berdiskusi dan berkolaborasi, berargumentasi dengan teman sekelas sehingga mereka dapat menemukan sendiri dan pada akhirnya menggunakan matematika itu untuk menyelesaikan masalah baik secara individu maupun kelompok. Pada PBM ini dosen berperan sebagai fasilitator, moderator atau evaluator sementara mahasiswa berpikir, mengkomunikasikan penalarannya, berkolaborasi menghargai pendapat orang lain.
Spasial merupakan kata serapan bahasa Inggris dari spatial dan kata spatial berasal dari kata space yang berarti ruang. Kemampuan spasial sering disamakan artinya dengan berbagai frasa seperti keahlian spasial, kemampuan visualisasi, kemampuan visual-spasial, persepsi spasial, kemampuan spasial konseptual, visualisasi dimensi tiga, kognisi visual, dan kemampuan visualisasi (Canturk-Gunhan, Turgut, Yilmaz, 2009).

Kemampuan spasial adalah kemampuan yang mencakup kemampuan berpikir dalam gambar, serta kemampuan untuk menyerap, mengubah, dan menciptakan kembali berbagai macam aspek dunia visual-spasial. Kemampuan spasial juga berkaitan dengan kemampuan menangkap warna, arah, dan ruang secara akurat. Amstrong mengatakan bahwa anak yang cerdas dalam visual-spasial memiliki kepekaan terhadap warna, garis-garis, bentuk-bentuk ruang, dan bangunan (Musfiroh, 2004).

Duch, Groh \& Allen (2001) mengungkapkan bahwa PBM mendorong kemampuan untuk mengidentifikasi informasi yang dibutuhkan untuk aplikasi tertentu, dimana dan bagaimana mencari informasi itu, bagaimana mengatur informasi dalam kerangka konseptual yang bemakna, dan bagaiman mengkomonikasikan kepada orang lain.

Arends \& Kilcher (2010) bahwa "problembased learning is a student-centered approach that organizes curriculum and instruction around carefully "ill-structured" and real-world problem situation". PBM merupakan suatu pendekatan yang berpusat pada siswa yang mengatur kurikulum dan pengajaran secara ketat pada situasi masalah yang "ill-structrured" dan masalah yang riil dalam kehidupan sehari-hari. Lebih lanjut dikatakan oleh Arends (2008: 51) bahwa PBL ditandai oleh siswa yang bekerja berpasangan atau dalam kelompok-kelompok kecil untuk menginvestigasi masalah kehidupan nyata yang membingungkan.

Amir (2010) menyebutkan 7 langkah dalam proses PBM sebagai berikut (1) mengklarifikasi istilah dan konsep yang belum jelas, (2) merumuskan masalah, (3) Menganilisis masalah, (4) menata gagasan dan secara sistematis menganalisis secara mendalam, 
memformulasikan tujuan pembelajaran, (6) mencari informasi tambahan dari sumber lain (di luar diskusi kelompok), (7) mensintesa (menggabungkan) dan menguji informasi baru, dan membuat laporan untuk kelas.

Geogebra dikembangkan oleh Markus Hohenwarter pada tahun 2001. Menurut Hohenwarter (2008), Geogebra adalah prgram komputer (software) untuk membelajarkan matematika khsusunya geometri dan aljabar. Program ini dapat dimanfaatkan secara bebas yang dapat diunduh dari www.geogebra.com.

Permadi \& Rudhito (2012) Geogebra merupakan salah satu program yang bersifat dinamis dan interaktif untuk mendukung terjadinya pembelajaran serta penyelesaian dalam masalah matematika khususnya geometri, aljabar dan kalkulus. Menurut Rusmawati \& Rudhito (2012) Geogebra dapat digunakan untuk memvisualisasikan objek-objek geometri. Geogebra adalah suatu sistem Geometri dinamis yang dapat membantu melakukan konstruksi dengan titik-titik, vektor-vektor, segment, bentuk, dan lainya.

Geogebra persamaan dan koordinat dapat di input secara langsung melalui sintak sederhana menyesuaikan bahasa/script yang digunakan oleh Geogebra. Geogebra mempunyai kemampuan yang berhubungan dengan numeris, vector, titik, menemukan derivatif, dan melakukan integral fungsi serta menawarkan perintah seperti akar, atau ekstremum. Berikut tampilan display awal dari Geogebra:

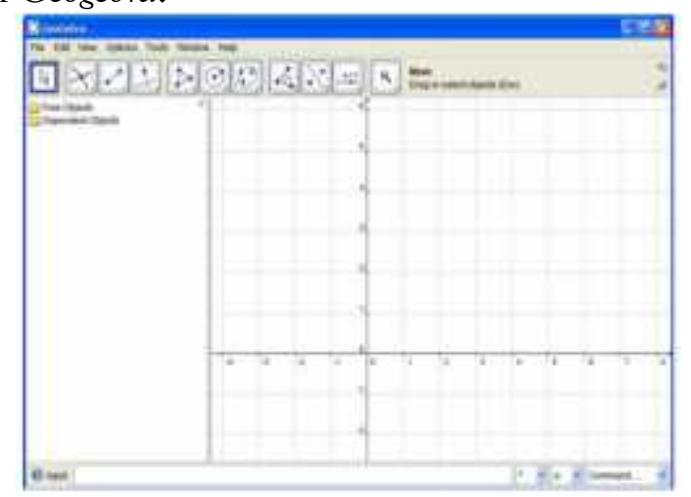

Gambar 1. Tampilan work sheet program Geogebra

Menurut Greenberg (1993) Geometri berasal dari bahasa Yunani yaitu geo yang artinya bumi dan metro yang artinya mengukur. Jadi geomteri adalah ilmu ukur bumi atau tanah. Pendapat lainnya, Brandenberger (2002) mengungkapkan Geometri adalah: "the branch of mathematics that deals with the properties and relationships of points, lines, angles, surfaces, planes, and solids". Yang berarti bahwa Geometri adalah cabang ilmu matematika yang berhubungan dengan sifat dan hubungan dari titik, garis, sudut, permukaan, bidang, dan volum.

Rich \& Thomas (2009) Geometri adalah mempelajari antara keterkaitan titik, garis, sudut dan bidang. Istilah-istilah dasar seperti titik, garis, sudut, luas dan kepadatan akan mendasari definisi semua istilah geometris lainnya, maka dari itu perlulah deskripsi yang baik untuk memaknai istilah titik, garis, sudut dan luas. Tanton (2005) menyebutkan bahwa dalam geometri Euclid, bangun dua dimensi disebut dengan geometri bidang datar dan bangun tiga dimensi disebut dengan geometri solid.

\section{METODE PENELITIAN}

Penelitan ini adalah penelitian eksperimen semu (quasi eksperiment), dengan desain pretestposttest non equivalent group design (Mertler \& Charles, 2005). Penelitian ini dilaksanakan di STKIP Taman Siswa Bima. Populasi dari penelitian adalah seluruh mahasiswa semester IV program studi Pendidikan Guru Sekolah Dasar. Pada penelitian ini sampel diambil secara acak dua kelas dari enam kelas yang ada, sehingga diperoleh kelas yaitu IVA dan IVB. Selanjutnya secara acak terpilih kelas IVA sebagai kelas yang akan diberikan perlakuan dengan PBM dengan bantuan Geogebra dan kelas IVB sebagai kelas yang akan diberikan perlakuan dengan pembelajaran konvensional.

Variabel dalam penelitian ini ada dua yaitu variabel bebas (independen) dan variabel terikat (dependen). Adapun variabel bebasnya adalah Pembelajaran Berbasis Masalah (PBM) dengan bantuan Geogebra, yang menjadi variabel terikat adalah kemampuan sapasial.

Instrumen yang digunakan dalam penelitian ini adalah tes kemampuan spasial matematika berupa soal uraian. Pemberian tes soal uraian tersebut diberikan pada awal (pretest) dan akhir pembelajaran (posttest). Skor yang diperoleh selanjutnya dikonversi sehingga menjadi nilai 
dengan rentang antara 0 sampai dengan 100. Skor tersebut kemudian digolongkan dalam kriteria berdasarkan standar nilai yang ditetapkan oleh prodi untuk mata kuliah Pembelajaran Matematika SD Kelas Lanjut yaitu 75. Nilai tersebut digunakan untuk menentukan persentase banyak mahasiswa yang mencapai kriteria ketuntasan.

\section{Teknik Analisis Data}

Analisis deskriptif digunakan untuk mendeskripsikan karakteristik data hasil penelitian dan menjawab permasalahan deskriptif. Analisis deskriptif yang digunakan dalam penelitian ini yaitu data pretest-posttest kemampuan spasial mahasiswa terhadap matematika berupa rata-rata, nilai maksimum, nilai minimum, standar deviasi dan presentase ketuntasan.

Analisis inferensial yang digunakan mulai dari uji asumsi yang harus dipenuhi yakni uji normalitas terhadap data pretest-posttest kemampuan spasial matematika pada kedua kelompok, menggunakan metode KolmogorovSmirnov dengan bantuan program SPSS 21 for Windows. Kriteria data berdistribusi normal jika nilai probabilitas lebih besar dari 0,05.

Tabel 1. Hasil Prestest dan Posttest Kemampuan Spasial Mahasiswa

\begin{tabular}{ccccc}
\hline \multirow{2}{*}{ Deskripsi } & \multicolumn{2}{c}{ PBM } & \multicolumn{2}{c}{ Konvensional } \\
\cline { 2 - 5 } & Pretest & Posttest & Pretest & Posttest \\
\hline Banyak Mahasiswa & 36 & 36 & 35 & 35 \\
\hline Rata-rata & 16,49 & 86,52 & 20,19 & 77,86 \\
\hline Nilai Maksimum & 41,67 & 97,92 & 37,50 & 93,75 \\
\hline Nilai Minimum & 6,25 & 72,92 & 6,25 & 56,25 \\
\hline Standar Deviasi & 7,61 & 7,21 & 8,75 & 9,10 \\
\hline Ketuntasan & $0 \%$ & $91,67 \%$ & $0 \%$ & $69,44 \%$
\end{tabular}

Data pada Tabel 1 di atas menunjukkan bahwa rata-rata pretest kelompok PBM dan konvensional berturut-turut 16,49 dan 20,19, sedangkan rata-rata posttest keduanya adalah 86,52 dan 77,86. Kemudian, prosentase ketuntasan pretest kelompok PBM dan Konvensional masing-masing $0 \%$ artinya tidak ada mahasiswa yang memenuhi kriteria tuntas, sedangkan setelah perlakuan ketuntasan

Tabel 2. Hasil Uji Normalitas Data Pretest dan Posttest

\begin{tabular}{cccccc}
\hline \multirow{2}{*}{ Data } & \multirow{2}{*}{ Kelas } & \multirow{2}{*}{ Variabel } & \multicolumn{3}{c}{ Kolmogorov-Smirnov } \\
\cline { 4 - 6 } & & & Statistik & Df & Sig. 2-tailed \\
\hline Pretest & PBM & K. Spasial & 0,929 & 35 & 0,355 \\
\hline
\end{tabular}




\begin{tabular}{lccccc}
\hline & Konvens & K. Spasial & 0,815 & 34 & 0,519 \\
\hline \multirow{2}{*}{ Posttest } & PMB & K. Spasial & 1,243 & 35 & 0,091 \\
\cline { 2 - 6 } & Konvens & K. Spasial & 0,776 & 34 & 0,584 \\
\hline
\end{tabular}

Berdasarkan Tabel 2 data uji normalitas mahasiswa. Uji ini dilakukan dengan bantuan univariat di atas, baik pretest maupun posttest diperoleh nilai signifikansi lebih dari 0,05 . Hal ini menunjukkan bahwa $\mathrm{H}_{0}$ diterima yang berarti data berdistribusi normal.

Selanjutnya uji keefektifan untuk mengetahui efektif atau tidaknya pembelajaran yang digunakan terhadap kemampuan spasial software SPSS 21 for windows menggunakan uji one sample t-test dengan taraf signifikansi $\alpha=0,05$ dengan derajat kebebasan adalah $36-1=35$. Nilai test value untuk kemampuan spasial adalah 75. Hasil uji tersebut dapat dilihat pada Tabel 3 berikut:

Tabel 3. Hasil Uji One Sample t-Test Dua Kelompok

\begin{tabular}{lccccc}
\hline Kelompok & Variabel & $t_{\text {hitung }}$ & Test-Value & Df & Sig. \\
\hline PMB & K. Spasial & 9,59 & 75 & 35 & 0,000 \\
\hline Konvens & K. Spasial & 1,86 & 75 & 34 & 0,002 \\
\hline
\end{tabular}

Berdasarkan Tabel 3 di atas, dapat diketahui bahwa pada kelompok PBM untuk variabel kemampuan spasial dengan test-value 75 diperoleh $t_{\text {hitung }}=9,59$, ini menunjukkan hasil signifikansi masing-masing sebesar $0,00<0,05$, maka $\mathrm{H}_{0}$ ditolak. Hal ini dapat disimpulkan bahwa PBM efektif ditinjau dari kemampuan spasial mahasiswa terhadap matematika.

Pada kelompok Konvensional untuk variabel kemampuan spasial dengan test-value 75 diperoleh $t_{\text {hitung }}=1,86$, nilai $t_{\text {hitung }}$ ini menunjukkan hasil signifikansi masing-masing sebesar 0,002 dan $0,000<0,05$, maka $\mathrm{H}_{0}$ ditolak. Hal ini dapat disimpulkan bahwa kemampuan spasial mahasiswa terhadap matematika.

Kemudian uji perbedaan keefektifan Pembelajaran Berbasis Masalah (PBM) dan metode Konvensional adalah pembelajaran yang sama-sama efektif ditinjau dari kemampuan spasial mahasiswa terhadap matematika dilakukan uji statistik ANOVA dengan tujuan untuk mengetahui apakah terdapat perbedaan mean antara keduanya ditinjau dari satu variabel terikat tersebut. Hasil analisis data dengan bantuan software SPSS 21 for windows dapat dilihat pada Tabel 4 berikut: pembelajaran Konvensional efektif ditinjau dari

Tabel 4. Hasil Uji ANOVA Data Posttest

\begin{tabular}{ccccc}
\hline Source & Type III Sum of Squares & Mean Square & $\mathrm{F}_{\text {hitung }}$ & Sig. \\
\hline Corrected Model & $1331.022^{\mathrm{a}}$ & 1331.022 & 19.829 & 0,000 \\
\hline
\end{tabular}

Berdasarkan Tabel $4 \mathrm{di}$ atas, dengan Tests of mahasiswa terhadap matematika, maka Between-Subjects Effects dilihat pada Corrected dilakukan uji lanjut $t$ univariat. Uji univariat Model diperoleh $\mathrm{F}_{\text {hitung }}$ sebesar 19.829 dengan dimaksudkan untuk melihat mana yang lebih taraf signifikansi yang diperoleh adalah 0,000 kurang dari 0,05 maka $\mathrm{H}_{0}$ ditolak. Dengan demikian, dapat disimpulkan bahwa terdapat perbedaan mean antara PBM dan metode pembelajaran Konvensional ditinjau dari kemampuan spasial mahasiswa terhadap matematika.

Berdasarkan hasil uji perbedaan keefektifan setelah perlakuan bahwa terdapat perbedaan keefektifan antara PBM dengan metode Konvensional ditinjau dari kemampuan spasial berpengaruh secara signifikan keduanya. Uji univariat yang dilakukan adalah menghitung nilai $t$ pada uji univariat (independent sample t-test) dengan kriteria uji adalah $\mathrm{H}_{0}$ ditolak jika nilai signifikansi lebih kecil dari $\alpha=0,05 / 2=0,025$. Uji ini menggunakan bantuan SPSS 21 for windows. Hasil uji independent sample t-test dapat dilihat pada tabel 5 berikut: 
Tabel 5. Hasil Uji Independent Sample t-Test Data Posttest

\begin{tabular}{ccccc}
\hline Variabel & $t_{\text {hitung }}$ & Df & Sig. & Keterangan \\
\hline K.Spasial & 4,45 & 69 & 0,000 & $\mathrm{H}_{0}$ ditolak \\
\hline
\end{tabular}

Berdasarkan Tabel 5 di atas, diketahui bahwa untuk kemampuan spasial pada kelompok PBM dan kelompok Konvensional diperoleh $t_{\text {hitung }}$ sebesar 4,45, kemudian nilai signifikansinya $0,000<0,025$ sehingga dapat disimpulkan $\mathrm{H}_{0}$ ditolak. Dengan demikian Pembelajaran Berbasis Masalah (PB) lebih berpengaruh secara signifikan dari motode Konvensional ditinjau dari kemampuan spasial matematika.

\section{KESIMPULAN}

Berdasarkan hasil analisis data, maka ada beberapa kesimpulan sebagai berikut: 1) Pembelajaran Berbasis Masalah (PBM) pada materi Geometri berbantuan Geogebra lebih berpengaruh secara signifikan terhadap kemampuan spaial matematika; 2) Metode pembelajaran Konvensional berpengaruh terhadap kemampuan spasial matematika; 3) Terdapat perbedaan keefektifan Pembelajaran Berbasis Masalah pada materi Geometri berbantuan Geogebra dengan pembelajaran Konvensional ditinjau dari kemampuan spasial matematika; 4) Pembelajaran Berbasis Masalah pada materi Geometri berbantuan Geogebra lebih berpengaruh secara signifikan dari metode pembelajaran Konvensional ditinjau dari kemampuan spasial matematika.

\section{DAFTAR PUSTAKA}

Ahmad \& Jaelani, A. 2015. Kemampaun spasial: Apa dan bagaimana cara meningkatkanya?. Jurnal Pendidikan Nusantra Indonesia, 1 (2). ISSN 2289 - 9375.

Amir, M., T. (2010). Inovasi pendidikan melalui problem based learning. Jakarta: Kencana Perdana media group.

Arends, R.I \& Kilcher, A. (2010). Teaching for student learning "becoming an accumplhised teacher". Madision Avenue: Routladge.

Arends, R., I. (2008). Learning to teach. (Terjemahan Helly Prajitno Soetjipto \& Sri Mulyantini Soetjipto). New York: McGraw
Hill Companies. (Buku Asli Diterbitkan tahun 2007). Jilid I.

Brandenberger, B.M. (2002). Mathematics. New York: Macmillan Reference

Canturk-Gunhan, B., Turgut, M., \& Yilmaz, S. (2009). Spatial Ability of a Mathemtics Teacher: the Case of Oya. IBSU Scientific Journal, 3 (1), 151-158.

Duch, B., J., Groh, S., E., \& Allen, D., E. (2001). The power of problem-based learning. Sterling, Virginia: Stylus.

Faradhila, N., Sujadi, I., \& Kuswardi, Y. (2013). Eksperimentasi Model Pembelajaran Missouri Mathematics Project (MMP) pada Materi Pokok Luas Permukaan serta Volume Prisma dan Limas Ditinjau dari Kemampuan Spasial Siswa Kelas VIII Semester Genap SMP Negeri 2 Kartasura. Jurnal Pendidikan Matematika Solusi, 1 (1), 67 - 74.

GCI (2011). Creativity and Prosperity: The global creativity index. Toronto: Martin Prosperity Institute.

Greenberg, M.J. (1993). Euclidean and development non-euclidean and history Geometries. New York: W.H. Freeman \& Company.

Hohenwarter, M., et al. (2008). Teaching and Learning Calculus with Free Dynamic Matgematics Software GeoGebra. Tersedia; http://geogebra.ir/geogebra/Files/PDF/6ad 63497da1a471a855558f30962f84e.pdf. [06 Juni 2017].

Lubinski, D. (2010). Spatial Ability and STEM: A Sleeping Giant for Talent Identification and Development. Elsevier, 49, 344 - 351.

Mahmudi, A. (2010). Membelajarkan Geometri dengan Program GeoGebra. Makalah terdapat pada Prosiding Seminar Nasional Matematika dan Pendidikan Matematika. Seminar diselengarakan oleh FPMIPA UNY bekerja sama dengan Himpunan Matematika Indonesia, ISBN : 978-979-16353-5-6.

Muslim \& Haris, A. 2017. Keefektifan Model Pembelajaran Kooperatif Tipe Group Investigation pada Materi Geometri Berbantuan Geogebra Ditinjau dari Self- 
Efficacy. Jurnal Pendidikan MIPA STKIP

Tamsis Bima, 7 (1), ISSN: 2088-0294.

Olkun, S. (2003). Making Connections: Improving Spatial Abilities with Engineering Drawing Activities. International Journal of Mathematics Teaching and Learning. Tersedia; http://acikarsiv.ankara.edu.tr/browse/4036 /4235.pdf. [04 Juni 2017].

Permadi, F.D \& Rudhito, M. A. 2012. Efektifitas Pembelajaran Dengan Programgeogebra Dibanding Pembelajaran Konvensional Pada Materi Teorema Pythagoras Kelas VIII SMP Pangudi Luhur Gantiwarno Klaten. Seminar Nasional Matematika dan Pendidikan Matematika UNY, P-35, ISBN: 978-979-16353-8-7, 326-334.

Rich, B. \& Thomas, C. (2009). Geometry (4 $4^{\text {th }} e d$.).

New York: The Mac-grawhill Companies inc.

Rusmawati, P.H \& Rudhito, M.A. Desain Lembar Kerja Siswa Dengan Pemanfaatan Program Geogebra Melalui Demonstrasi Pada Materi Kesebangunan di Kelas IX SMP Negeri 2 Jetis Bantul. Seminar Nasional Matematika dan Pendidikan Matematika UNY, P-71, ISBN : 978-979-16353-8-7, 672-680.

Tanton, J. (2005). Encylopedia of mathematics. New York: Library of Congres Cataloging.

Turgut, M. \& Yilmaz, S. (2012). Relationship among Preservice Primary Mathematics Teachers' Gender, Academic Success, and Spatial Ability. International Journal of Instruction, 5 (2), 5 - 20. 